\title{
Dinoflagellate resting cysts as factors in phytoplankton ecology of the North Sea
}

\author{
S. Nehring \\ Institut für Meereskunde an der Universität Kiel; Düsternbrooker Weg 20, D-24105 Kiel, \\ Germany
}

\begin{abstract}
The occurrence and distribution of dinoflagellate resting cysts were investigated at 11 locations in the south-eastern part of the North Sea. Twenty-six known cyst species and 7 unknown cyst types, which may act as seed population for planktonic dinoflagellate blooms, have been recorded for the first time in the area. The most common cysts in recent sediments were those of Scrippsiella trochoidea, Zygabikodinium lenticulatum, Peridinium dalei, Scrippsiella lachrymosa, Protoceratium reticulatum, Protoperidinium denticulatum, and $P$. conicum. At all stations, $S$. trochoidea dominated the cyst assemblages with a maximal abundance of $1303 \mathrm{living} \mathrm{cysts} / \mathrm{cm}^{3}$ in the uppermost half centimetre. Cysts of the potentially toxic dinoflagellates Alexandrium cf. excavatum and $A$. cf. tamarense were scarce. In the upper 2-cm layer of sediment, dinoflagellate cysts were found in concentrations of 1.8 up to 682 living cysts $/ \mathrm{cm}^{3}$. Empty cysts constituted $22-56 \%$ of total cyst abundance. The comparative distribution of the cysts showed a general increase in abundance from inshore sites to the offshore area, whereby sandy stations exhibited the lowest cyst abundance and diversity. The wide distribution of living and empty cysts of Scrippsiella lachrymosa suggests that its motile form, which has not been officially recorded in the area until now, is a common plankton organism in German coastal waters. The relatively high abundance of cysts in recent sediments demonstrates the potential importance of benthic resting stages for the initiation of dinoflagellate blooms in the study area.
\end{abstract}

\section{INTRODUCTION}

Many plankton groups include a non-motile dormant egg or cyst stage in their life history (e.g. copepods, cladocerans, tintinnids, diatoms, and dinoflagellates). Dinoflagellate cysts are known to geologists as an important group of microfossils ('hystrichospheres') used extensively for biostratigraphy (e.g. in oil exploration). More than 100 years ago, living dinoflagellate resting cysts were first observed in plankton samples of the North Sea (Stein, 1883; Hensen, 1887; Möbius, 1887) and were occasionally mentioned in the phycological literature, which mainly dealt with freshwater environment during the first half of the twentieth century (e.g. Zederbauer, 1904; Lohmann, 1910; Klebs, 1912; Diwald, 1938; Braarud, 1945; Nordli, 1951). Detailed investigations were, however, not carried out until the 1960 s with the pioneering work of the palaeontologists Evitt \& Davidson (1964), Wall (1965) and Wall \& Dale (1966, 1968a, b) which showed the cyst-theca relationships of modern dinoflagellates. Regardless of these new areas for algologists and with the tradition of the first detection of cysts in the late 1800 s by Stein, Hensen and Möbius, little is known about the ecological importance of dinoflagellate cysts in recent sediments, especially in the south-eastern part of the North Sea. 
Two types of cysts are found in dinoflagellate life cycles: (1) the asexually formed temporary cyst, and (2) the resting cyst, the formation of which is the consequence of a sexual process (Dale, 1983). Both types of cysts lack a flagella and accumulate on the sea bottom.

At present many aspects of the timing, location, and duration of dinoflagellate blooms have been linked to the encystment/excystment cycle of those species that form resting cysts during their life histories (Huber \& Nipkow, 1922; Steidinger, 1975; Anderson \& Wall, 1978; Anderson \& Morel, 1979; Anderson et al., 1983; Burkholder et al., 1992). Ecological studies concerning temporary cysts are few, because the occurrence of the latter in natural waters has rarely been recorded. But there is some evidence that the mechanism of the formation of temporary cysts is important in relation to the persistence and recurrence of red tides in a certain limited area throughout the summer (Marasovic, 1989; Nehring, 1992).

Within the framework of the "Ecosystem Research Wadden Sea Project, Part A", phytoplankton and their resting stages in brackish-water bodies of the German North Sea coast are investigated. The present publication documents the occurrence, distribution and abundance of dinoflagellate resting cysts in recent sediments of the North Sea, for the purpose of estimating their potential importance in initiating menacing algal blooms in coastal zones of the North Sea.

\section{MATERIALS AND METHODS}

Undisturbed surface sediment samples of the North Sea were collected with a Reineck box corer during the RV Meteor cruise (No. 19) from 30th September to 11th October 1991 and with a modified Jonasson \& Olansson (1966) box sampler during the RV Gauss cruise (No. 202) from 5th March to 12th March 1992 (Table 1). Duplicate sediment cores $(10 \mathrm{~cm}$ long, $2.6 \mathrm{~cm}$ diameter) were obtained with the corer and were stored in the dark at $4^{\circ} \mathrm{C}$ until further examination.

Each core was processed using a modified biological technique of Anderson et al. (1982) and Matsuoka et al. (1989) without any chemicals. The upper 2 or $3 \mathrm{~cm}$ of a sediment core was partitioned into $0.5 \mathrm{~cm}$ up to $1 \mathrm{~cm}$ depth, the rest in $1 \mathrm{~cm}$ horizontal intervals and mixed with filtered seawater. These subsamples were sonicated for $1 \mathrm{~min}$ in an ultrasonic cleaning bath (Bransonic 52) to separate the cysts from organic and inorganic aggregates. The suspension was passed through a $150 \mu \mathrm{m}$ gauze and accumulated on a $20 \mu \mathrm{m}$ gauze. The residue on the $20 \mu \mathrm{m}$ gauze was rewashed and filled up with filtered seawater to make up a final volume of $20 \mathrm{ml}$. Several $1000 \mu \mathrm{l}$ aliquots up to the whole $20 \mathrm{ml}$ of this preparation were counted on common slides using an Olympus light microscope or on Utermöhl slides using a Zeiss Axiovert inverted microscope. Living cysts (containing protoplasm) and empty cysts were separately quantified.

Most of the cysts were identified according to descriptions given in the extensive literature about cysts. Palaeontologists and biologists often use different names for the life history stages of the same dinoflagellate. The biological (thecate) names of species were used in this study.

Unknown cysts and individual cysts were used for germination experiments to identify the species by the motile thecate cell. For this purpose, cysts were picked out from Utermöhl slides, using a micropipette, and washed twice in filtered seawater. The 
Table 1. Positions, water depth and sediment type of the North Sea stations. M: RV Meteor; G: RV Gauss

\begin{tabular}{|c|c|c|c|c|}
\hline Station & Coordinates & $\begin{array}{l}\text { Water depth } \\
\text { (m) }\end{array}$ & Sampling date & Sediment type \\
\hline M644 & $\begin{array}{r}55^{\circ} 35,89^{\prime} \mathrm{N} \\
4^{\circ} 59,78^{\prime} \mathrm{E}\end{array}$ & 44 & 6. 10.91 & muddy sand \\
\hline M645 & $\begin{array}{r}55^{\circ} 43,95^{\prime} \mathrm{N} \\
6^{\circ} 25,02^{\prime} \mathrm{E}\end{array}$ & 44 & 6.10 .91 & sandy mud \\
\hline M668 & $\begin{array}{r}54^{\circ} 15,01^{\prime} \mathrm{N} \\
7^{\circ} 29,46^{\prime} \mathrm{E}\end{array}$ & 41 & 10. 10.91 & sandy mud \\
\hline M671 & $\begin{array}{r}54^{\circ} 14,00^{\prime} \mathrm{N} \\
8^{\circ} 22,80^{\prime} \mathrm{E}\end{array}$ & 14 & 10. 10.91 & muddy sand \\
\hline G4 & $\begin{array}{r}55^{\circ} 00,00^{\prime} \mathrm{N} \\
6^{\circ} 13,82^{\prime} \mathrm{E}\end{array}$ & 45 & 6.3 .92 & sandy mud \\
\hline G9 & $\begin{array}{r}54^{\circ} 59,79^{\prime} \mathrm{N} \\
8^{\circ} 15,04^{\prime} \mathrm{E}\end{array}$ & 15 & 7. 3.92 & sand \\
\hline G11 & $\begin{array}{r}54^{\circ} 39,88^{\prime} \mathrm{N} \\
6^{\circ} 45,20^{\prime} \mathrm{E}\end{array}$ & 39 & 8. 3.92 & sandy mud \\
\hline G20 & $\begin{array}{r}54^{\circ} 50,01^{\prime} \mathrm{N} \\
8^{\circ} 00,02^{\prime} \mathrm{E}\end{array}$ & 16 & 10. 3.92 & sand \\
\hline G35 & $\begin{array}{r}54^{\circ} 05,00^{\prime} \mathrm{N} \\
7^{\circ} 50,00^{\prime} \mathrm{E}\end{array}$ & 44 & 11. 3.92 & sandy mud \\
\hline G36 & $\begin{array}{r}53^{\circ} 40,67^{\prime} \mathrm{N} \\
6^{\circ} 25,09^{\prime} \mathrm{E}\end{array}$ & 25 & 8. 3.92 & sand \\
\hline GE4 & $\begin{array}{r}54^{\circ} 08,43^{\prime} \mathrm{N} \\
8^{\circ} 07,04^{\prime} \mathrm{E}\end{array}$ & 23 & 11.3 .92 & mud \\
\hline
\end{tabular}

cysts were then placed in small sterile incubation chambers (Corning Cell Wells) and filled up with the filtered seawater from the sample location or the medium F/2 (Guillard $\&$ Ryther, 1962). The cysts were kept at room temperature $\left(\approx 18^{\circ} \mathrm{C}\right)$ under natural light conditions and were examined regularly for germination. If they had not germinated within 14 days, the experiment was abandoned.

For Scanning Electron Microscopy, the cysts were again individually picked out and mounted on Nucleopore filters. These were fixed with $2 \%$ formaldehyde for $24 \mathrm{~h}$, dehydrated in an acetone sequence and subsequently air dried. After sputter coating with gold-palladium (Balzers SCD 004), cysts were examined in a Zeiss DSM 940.

Separate sediment samples (top $1-\mathrm{cm}$ layer) were used for determining the ignition loss of the organic content by combusting the organic material for $24 \mathrm{~h}$ at $550^{\circ} \mathrm{C}$.

\section{RESULTS}

\section{Occurrence of resting cysts}

More than seventy species of marine and more than twenty species of freshwater planktonic dinoflagellates produce a resting cyst as part of their sexual life cycle (Nehring, 1993a). For the German North Sea coast, motile thecate stages of 45 cyst- 
Table 2. Motile stage of resting cyst-forming dinoflagellate species recorded by Drebes \& Elbrächter (1976) and Elbrächter (pers. comm.) in the south-eastern North Sea. ${ }^{+}$benthic species

\begin{tabular}{|lll|}
\hline Alexandrium affine & Gonyaulax verior & Protoperidinium divaricatum \\
Alexandrium excavatum & Gyrodinium instriatum & Protoperidinium divergens \\
Alexandrium lusitanicum & Gyrodinium uncatenum & Protoperidinium excentricum \\
Alexandrium ostenfeldii & Katodinium fungiforme & Protoperidinium leonis \\
Alexandrium pseudogonyaulax & Oblea rotunda & Protoperidinium minutum \\
Alexandrium tamarense & Peridinium dalei & Protoperidinium oblongum \\
Amphidinium carterae & Polykrikos kofoidii & Protoperidinium pentagonum \\
Coolia monotis & Polykrikos schwartzii & Protoperidinium punctulatum \\
Diplopelta parva & Prorocentrum lima & Protoperidinium subinerme \\
Diplopsalis lebourae & Protoceratium reticulatum & Protoperidinium thorianum \\
Diplopsalis lenticula & Protoperidinium avellana & Protoperidinium thulesense \\
Diplopsalopsis orbicularis & Protoperidinium claudicans & Pyrophacus horologium \\
Gonyaulax digitales & Protoperidinium conicoides & Pyrophacus steinii var. steinii \\
Gonyaulax scrippsae & Protoperidinium conicum & Scrippsiella trochoidea \\
Gonyaulax spinifera & Protoperidinium denticulatum & Zygabikodinium lenticulatum \\
\hline
\end{tabular}

forming species are recorded (Drebes \& Elbrächter, 1976; Elbrächter, pers. comm. See Table 2), but no detailed information about the presence of dinoflagellate cysts is available for this region.

The present study reveals that living and empty cysts are widespread throughout the investigated stations. Altogether, 26 different cyst types were identified on species level (Table 3; Figs 1, 2). Several species were additionally identified from motile cells germinated by single-cyst incubation experiments (Gonyaulax polyedra, Peridinium dalei, Polykrikos schwartzii, Protoceratium reticulatum, Protoperidinium conicoides, $P$. conicum, $P$. denticulatum, $P$. leonis, $P$. minutum, $P$. oblongum, $P$. cf. punctulatum, Scrippsiella trochoidea). For German coastal sediments (Stat. M671, G9, G20, G35, GE4), 20 cyst forms of the 45 motile cyst-forming species occurring in the region were detected, whereby for Gonyaulax spinifera, Polykrikos kofoidii (Figs 1H, I), Protoperidinium conicoides (Fig. 1O), P. divaricatum (Fig. 1R) and P. pentagonum (Fig. 1U), only empty cysts were found. Gonyaulax spinifera can produce different cyst types (Fig. 1E, F), presumably in response to different environmental conditions (Taylor \& Gaines, 1989). These were designated here as a group. To date, at least 6 cyst types have been found to germinate to a thecate cell of Gonyaulax spinifera (Dodge, 1989). In the palaeontological taxon, numerous cyst types of Gonyaulax spinifera are differentiated. Possibly this extremely varied cyst type indicates that it is, in fact, a species complex.

The most common species, in order of decreasing abundances of living cysts, were Scrippsiella trochoidea (Figs 2A-C), Zygabikodinium lenticulatum (Fig. 1V), Peridinium dalei (Fig. 1G), Scrippsiella lachrymosa (Figs 2D-F), Protoceratium reticulatum (Figs 1L, M), Protoperidinium denticulatum (Fig. 1Q), and P. conicum (Fig. 1P). Cysts of the potentially toxic Alexandrium cf. excavatum (Fig. 1A), A. cf. tamarense (Fig. 1B) and of the potentially noxious bloom-forming Gonyaulax polyedra (Fig. 1D) were restricted mainly to the offshore area. The wide distribution of living and empty cysts of Scrippsiella lachrymosa suggests that this form, in addition to $S$. trochoidea, is a common plankton organism in German coastal waters. However, motile forms of $S$. lachrymosa have not 


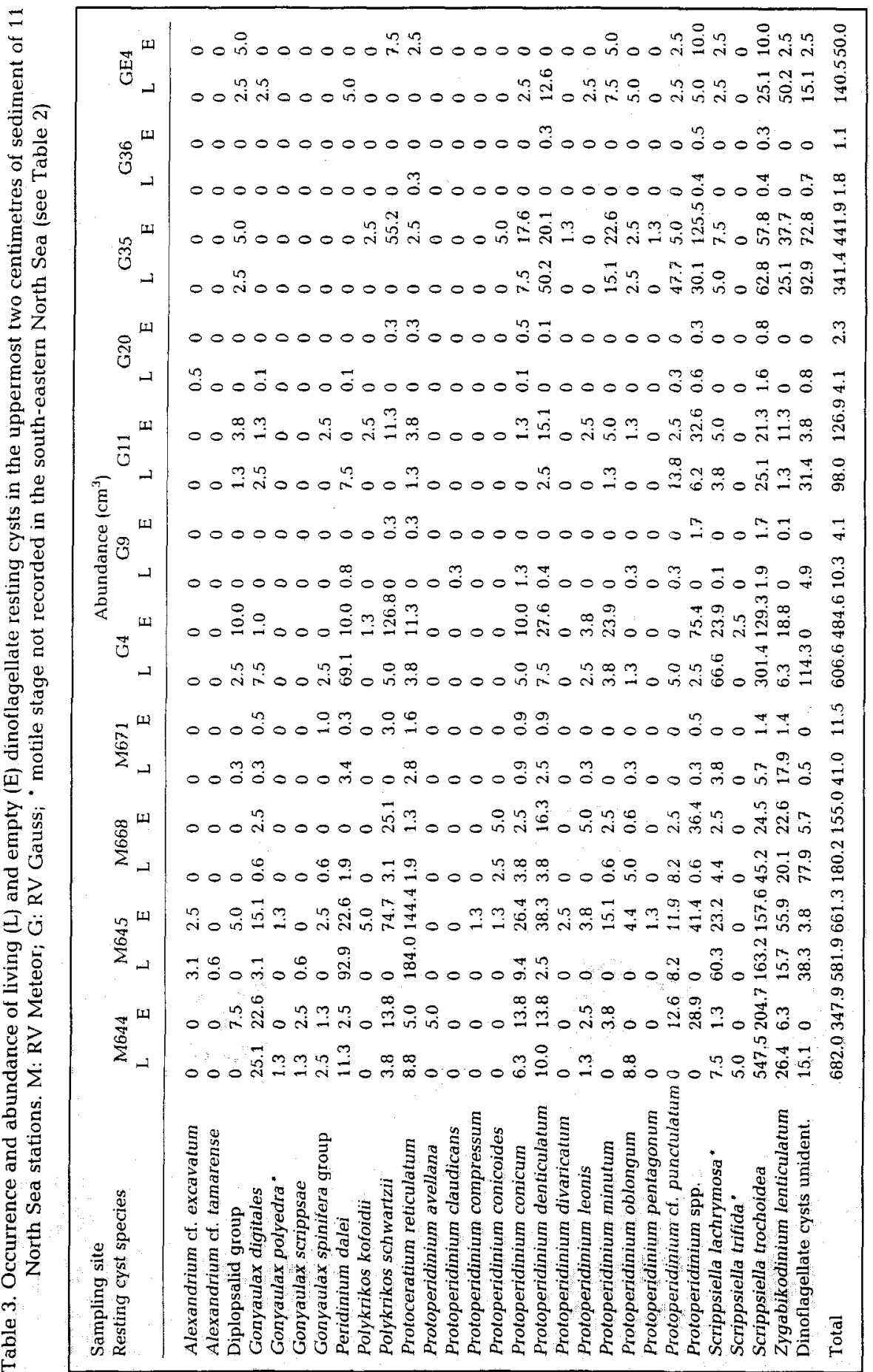


S. Nehring
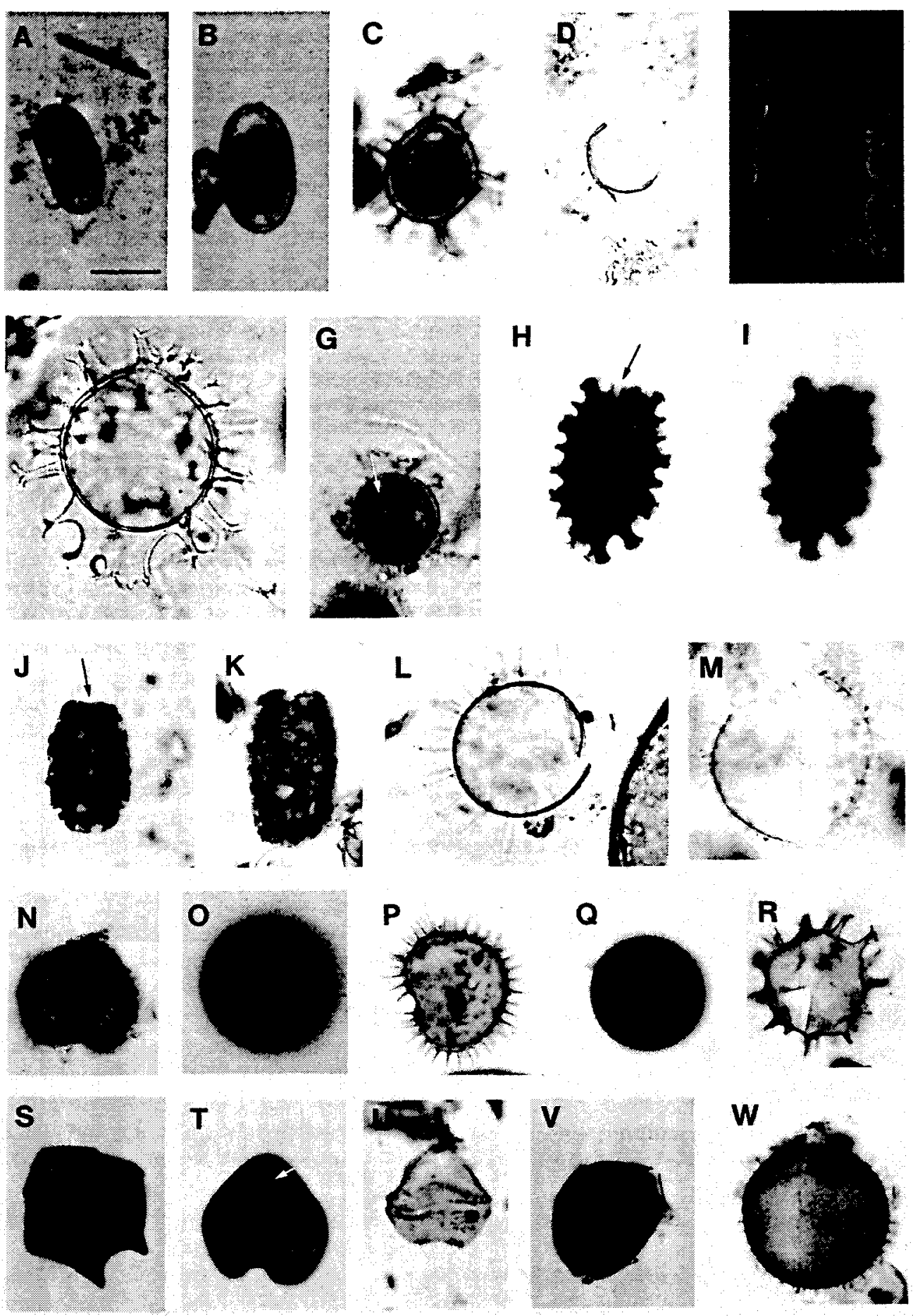
been officially recorded so far in the region (Elbrächter, pers. comm.). Probably they have been overlooked because of their small size and the difficulty to distinguish them from closely related orthoperidinoid species. In contrast to this, the cysts of Scrippsiella species possess unequivocal morphological distinguishing features. The cyst of $S$. trochoidea has a highly variable, ovoid to spherical form, dark greyish-coloured with a bright red accumulation body often visible (Figs 2A-C). The cyst is 25 to $48 \mu \mathrm{m}$ long and 25 to $44 \mu \mathrm{m}$ wide, covered by numerous calcareous spines up to $10 \mu \mathrm{m}$ long. The spine shafts terminate in blunt, capitate or pointed ends. The archeopyle (excystment aperture in the cyst wall) is a split towards one end of the cyst, forming a cap-shaped operculum. The cyst of S. lachrymosa has an elongate oval form and is covered with thin, flattened calcareous plates which are jointly indented (Figs 2D-F). The cyst is 35 to $47 \mu \mathrm{m}$ long and 17 to $35 \mu \mathrm{m}$ wide. A bright red accumulation body is visible and the archeopyle is a smooth split towards the cyst-apex. Only a few cysts of $S$. trifida were found offshore. The shape of this cyst is oval with a length of 29 to $41 \mu \mathrm{m}$ and a width of 21 to $30 \mu \mathrm{m}$ (Fig. 2G). The cyst wall is covered by a number of trifurcate, recurved, calcareous spines, and a red body is often visible. The archeopyle was not detected, but Lewis (1991) described it as an apical split which is sometimes notched, remaining attached to one side of the main body of the cyst.

In addition to the identified forms, 7 unknown cyst types were found. Unfortunately, in these cases germination experiments were not very successful. One of these cyst types (Fig. 1W) (isolated at G35, G36, GE4) was brown and spherical (38 to $40 \mu \mathrm{m}$ diameter, excl. spines) with numerous slender, curved spines ( 2 to $5 \mu \mathrm{m}$ long). Numerous small plastids and oil globules occur within the microgranular protoplasm. One cyst was germinated to give a motile thecate cell and was identified as Protoperidinium cf. curvipes. At present this cyst-theca relationship is unknown $n_{i}$ therefore, further examinations are in progress. At Station M645, a spherical ( $34 \mu \mathrm{m}$ diameter) pale brown cyst with a loosely-attached and folded, membranous outer layer was found. This cyst type is similar to Protoperidinium americanum, which, however, is not well known and the thecate cell has not been previously recorded in the North Sea region. Two of the unknown cyst types were of quantitative importance in the central part of the investigated area (G4, G11, M668). Both cysts are spherical with a pale content, and pale yellow/orange accumulation bodies are present. Cyst walls are colourless but both are

Fig. 1. Dinoflagellate resting cysts, isolated from recent North Sea sediments. A: Alexandrium cf. excavatum. B: Alexandrium cf. tamarense. C: Gonyaulax digitalis. D: Empty cyst of Gonyaulax polyedra. E-F: Empty cysts of Gonyaulax spinifera group, E: Palaeontological taxon Spiniferites elongatus; F: Palaeontological taxon Spiniferites mirabilis. G: Peridinium dalei, cell contents with red body (arrow). H-I: Empty cyst of Polykrikos kofoidii, H: Optical cross-section, archeopyle (arrow); I: Surface detail showing rows of hollow processes which sometimes connect adjacent ones. J-K: Empty cysts of Polykrikos schwartzii, J: Optical cross-section, archeopyle (arrow); K: Surface detail showing complex reticulate network of processes. L-M: Empty cysts of Protoceratium reticulatum showing variation in process morphology, $\mathrm{L}$ : Cyst with long tapering spines with capitate tips; M: Cyst with short processes (nodular form). N: Protoperidinium claudicans. O: Empty cyst of Protoperidinium conicoides with archeopyle. P. Empty cyst of Protoperidinium conicum. Q: Empty cyst of Protoperidinium denticulatum with archeopyle. R: Empty cyst of Protoperidinium divaricatum. S: Empty cyst of Protoperidinium leonis with archeopyle. T: Protoperidinium oblongum, cell contents with red oil globules (arrow). U: Empty cyst of Protoperidinium pentagomum. V: Zygabikodinium lenticulatum, cyst enclosed within the theca. W: Unidentified cyst, probably cyst of Protoperidinium curvipes. Scale bar: $40 \mu \mathrm{m}$ in A-D, G-K, N, P, R-V, $20 \mu \mathrm{m}$ E, F, L, M, O, Q, W 

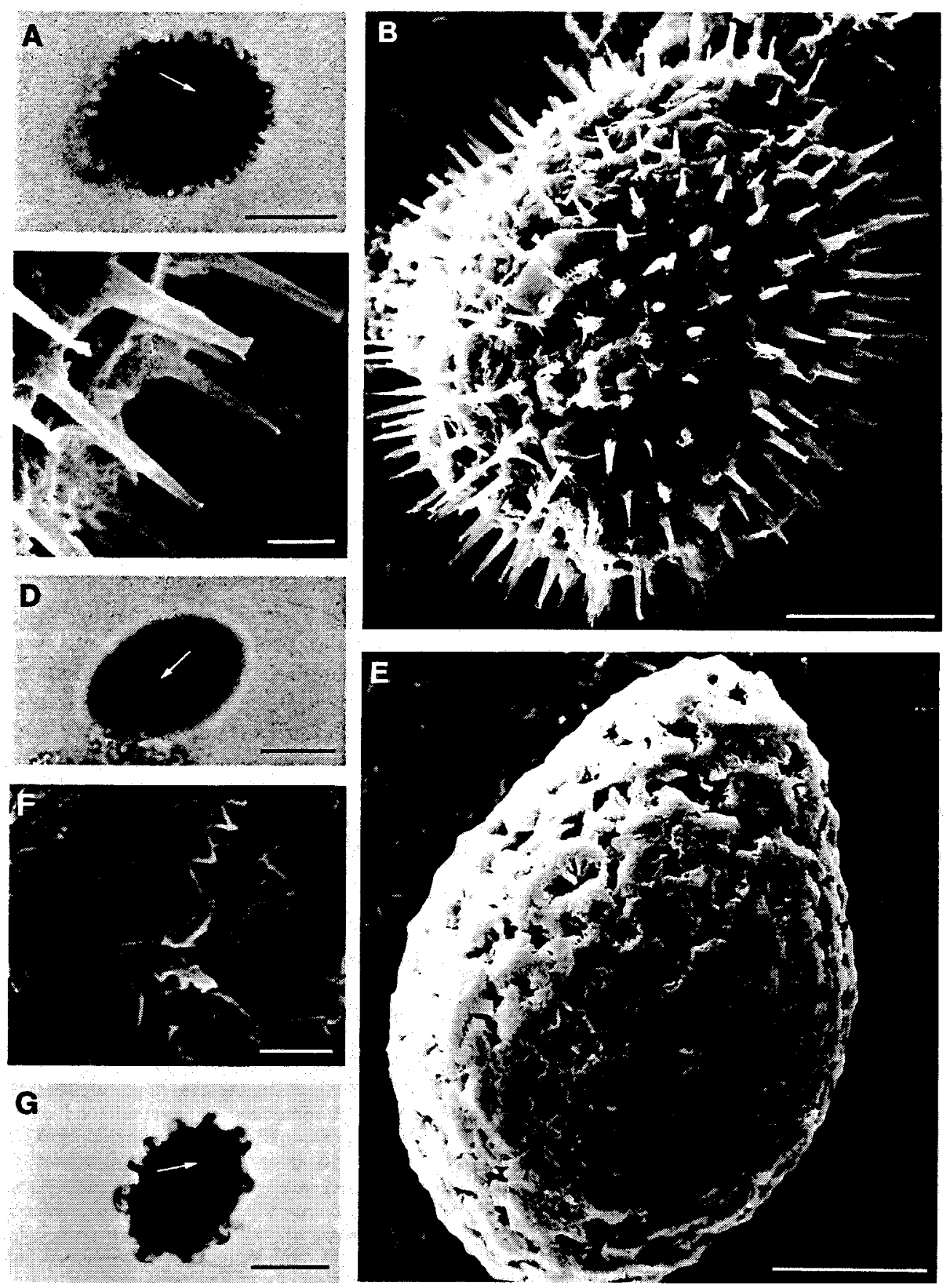

Fig. 2. Scrippsiella resting cysts, isolated trom recent North Sea sediments. A-C: Scrippsiella trochoidea, A: Living cyst showing red body (arrow); B: SEM, cyst with numerous calcareous spines; C: SEM, detail of ornament. D-F: Scrippsiella lachrymosa, D: Living cyst showing red body (arrow); E: SEM, cyst showing calcareous ornament; F: SEM, detail of ornament. G: Scrippsiella trifida, living cyst showing red body (arrow). Scale bars: $20 \mu \mathrm{m}$ in A, D, G; $10 \mu \mathrm{m}$ in B, E, $2 \mu \mathrm{m}$ in C, F 
significantly different in size (19 to $25 \mu \mathrm{m}$ diameter and 48 to $55 \mu \mathrm{m}$ diameter respectively). Previously, a clear cyst type, similar to the former, was described from uni-algal Scrippsiella trochoidea cultures (e.g. Braarud, 1957). A few spherical, brown cysts (30 to $52 \mu \mathrm{m}$ diameter) with a coarsely granular surface and with a long slit as archeopyle were found; however, these cysts were frequently deformed. An identification was not possible because this cyst type includes several species (Diplopsalis lebourae, D. lenticula, Diplopsalopsis orbicularis, Gotoius abei, Oblea rotunda) and were designated in this study as the 'Diplopsalid group'. Reticulate cysts (30 um diameter; from Stations G11 and G35) of the 'Diplopsalid group' produced motile cells after incubation which were comparable to the toxic, chainforming Gymnodinium catenatum (Nehring, 1993b). The several living or empty, spherical, brown cysts (35-68 um diameter) which were found either did not germinate in experiments (living cysts) or were compressed (empty cysts) and were designated in the study as Protopinchnium spp. At Station M671 one large spherical, brown, living cyst (90 $\mu \mathrm{m}$ diameter) belonging to Protoperidinium was found. Reid (1977) isolated a similar, large but empty cyst, with hexagonal archeopyle, from recent North Sea sediments and assigned it to the palaeontological taxon Brigantedinium majusculum. At present, the thecal affinity is unknown. Near Helgoland (GE4), an elongate ovoidal grey cyst ( $105 \mu \mathrm{m}$ long, $73 \mu \mathrm{m}$ wide) was found, bearing numerous naps (diameter up to $14.5 \mu \mathrm{m}$ ) (cf. Nehring, 1993a; Figs 5G, H). The cyst morphology and the circular, "tremic" archeopyle (sensu Matsuoka, 1985) suggest that this unknown cyst type belongs to Polykrikos, which most likely represents a new cyst-theca relationship. At present, in Polykrikos only the distinctive cysts of $P$. koifodii (Figs $1 \mathrm{H}, \mathrm{I}$ ) and $P$. schwartzii (Figs $1 \mathrm{~J}, \mathrm{~K}$ ) are known and were found in this study, too.

\section{Distribution of resting cysts}

For interpretation of the distribution patterns of resting cysts, it is necessary to describe the sediment characteristics of the investigated stations (Table 1). The sediments vary from sand (G9, G20, G36), to fine sand with mud (M644, M671) and mud with fine sand (M645, M668, G4, G11, G35) with the finest sediments occurring near Helgoland (GE4). The organic content varied between 0.3 and $10.2 \%$, being lowest at sandy stations and highest at site GE4.

The comparative distribution of the cysts showed a general increase in abundances from the inshore areas to the offshore area (Fig. 3) and are also closely related to sediment type. In the upper $2-\mathrm{cm}$ sediment layer, living dinoflagellate cysts were found offshore in concentrations of $682 \mathrm{cysts} / \mathrm{cm}^{3}$ at the muddy sand station (M644) and $582-607 \mathrm{cysts} / \mathrm{cm}^{3}$ at the sandy mud stations (M645, G4). Empty cysts constituted $34-53 \%$ of the total cyst abundance. The sandy coastal stations (G36, G20, G9) were characterized by the lowest cyst abundances (1.8-10.3 living cysts $\left./ \mathrm{cm}^{3}\right)$. The fraction of empty cysts was $28-37 \%$ of the total cyst counts. The muddy sand inshore station contained a concentration of 41 living cysts $/ \mathrm{cm}^{3}$ (M671). At the sandy mud stations, living cysts were found in concentrations of $98-341$ cysts $/ \mathrm{cm}^{3}$ (G11, M668, G35) and 141 living cysts $/ \mathrm{cm}^{3}$ were found the mud station (GE4). Empty cysts constituted $22-56 \%$ of the total cyst abundance.

The species diversity of living cysts varied between 2 (G36) and 15 (M644) and for empty cysts between 2 (G36) and 21 (M645). Species richness may be somewhat higher offshore than in the inshore areas. This difference becomes even more obvious when rare species $\left(<1\right.$ cysts $\left./ \mathrm{cm}^{3}\right)$ are excluded. 


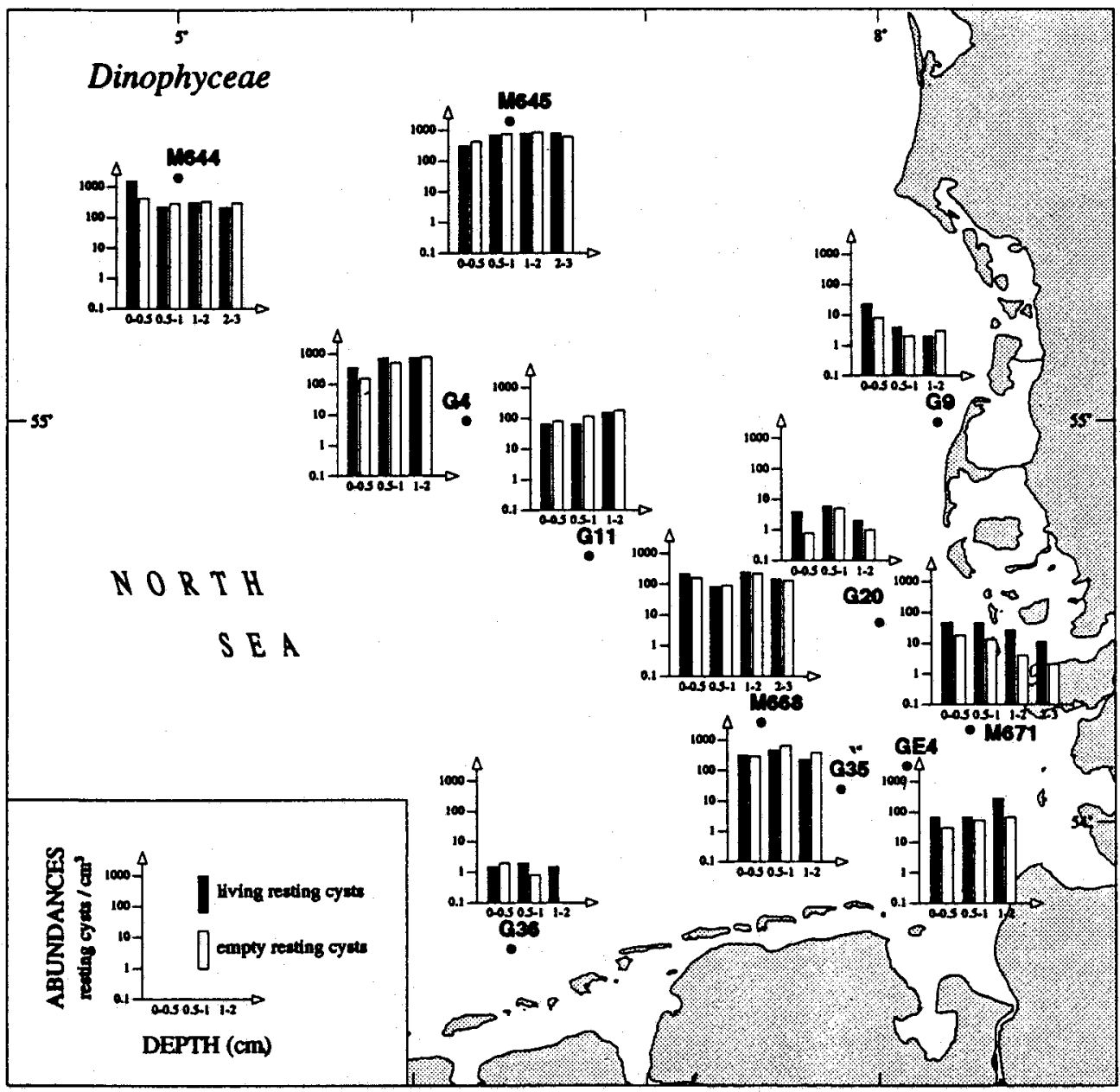

Fig. 3. Horizontal and vertical distribution of living and empty resting cysts of dinoflagellates in the uppermost centimetres of sediment of the south-eastern North Sea (M: RV Meteor, October 1991; G: RV Gauss, March 1992)

The cyst distribution and abundances of three common species Scrippsiella trochoidea, Zygabikodinium lenticulatum and Protoceratium reticulatum are given in Figures 4 to 6 . At all stations, Scrippsiella trochoidea dominated the cyst assemblages. Living cysts of $S$. trochoidea obtained a percentage of up to $80 \%$ in the uppermost $2-\mathrm{cm}$ sediment layer at the offshore Station M644. The cysts of Zygabikodinium lenticulatum were more abundant in the northern part (M644, M645) and at stations around Helgoland than at the other coastal stations or in the central part of the investigated area. In contrast, abundances of Protoceratium reticulatum cysts were highest offshore (M645) and lowest at the coastal sites. At three stations in the coastal water, only empty cysts of this species were found. 


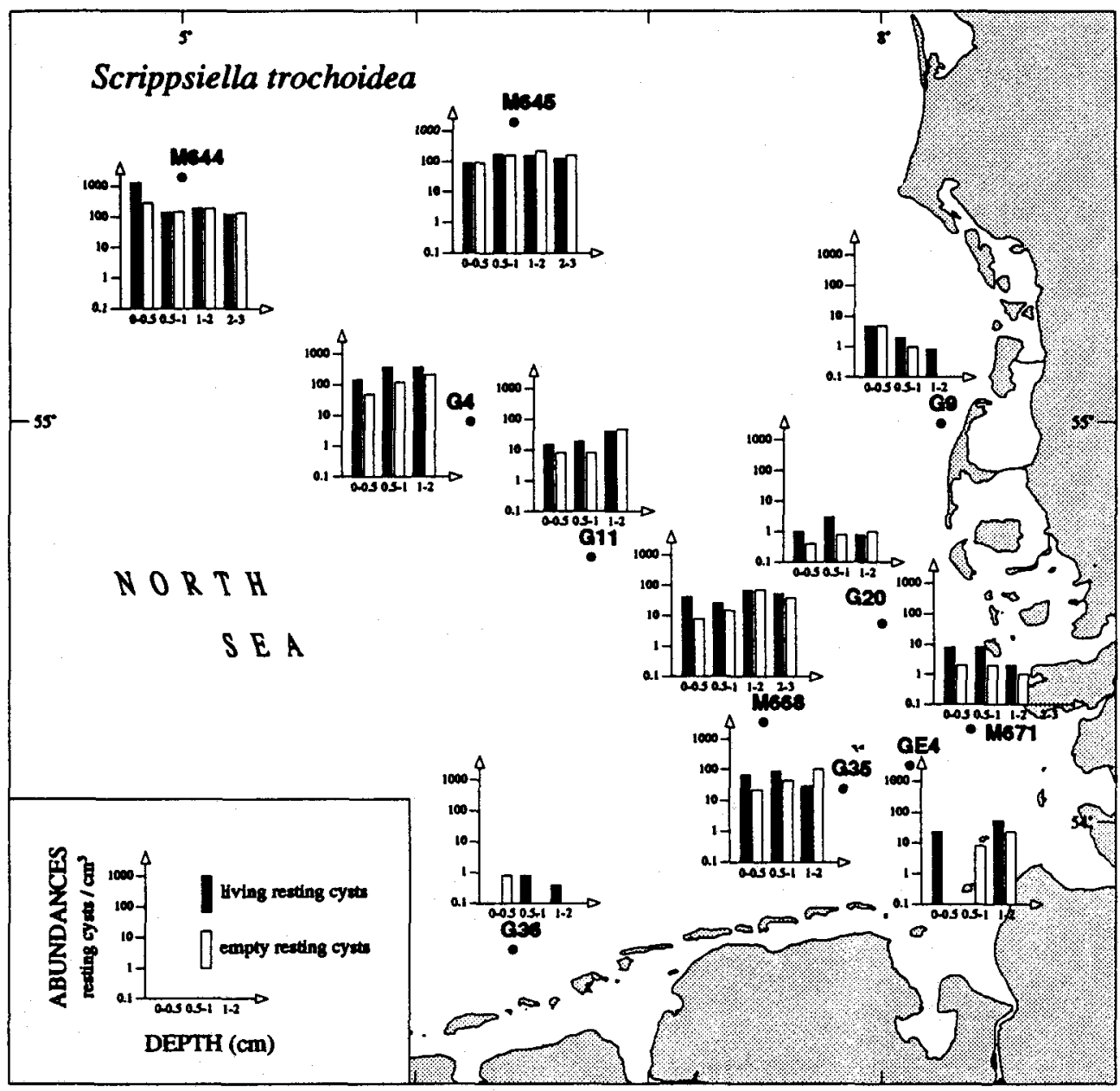

Fig. 4. Horizontal and vertical distribution of living and empty resting cysts of the dinoflagellate Scrippsiella trochoidea in the uppermost centimetres of sediment of the south-eastern North Sea (M: RV Meteor, October 1991; G: RV Gauss, March 1992)

Alexandrium cf. excavatum cysts were only found in a few sediment layers at two stations (M645, G20) in very low abundances ( $\max 9.4$ living cysts $/ \mathrm{cm}^{3}$ ). The cysts of $A$. cf. tamarense were only detected at Station M645, and in even lower abundances than the former species.

The small-scale vertical distribution of living and empty cysts usually exhibited maximum concentrations well below the sediment surface. In this context, the maximal abundance of 1303 living cysts $/ \mathrm{cm}^{3}$ of Scrippsiella trochoidea in the uppermost half centimetres of sediment at Station M644 is a remarkable exception, which may be a result of a recent bloom of $S$. trochoidea which ceased at this station.

At mnst stations the ratio hetween living and emntv cysts of abundant species in all 


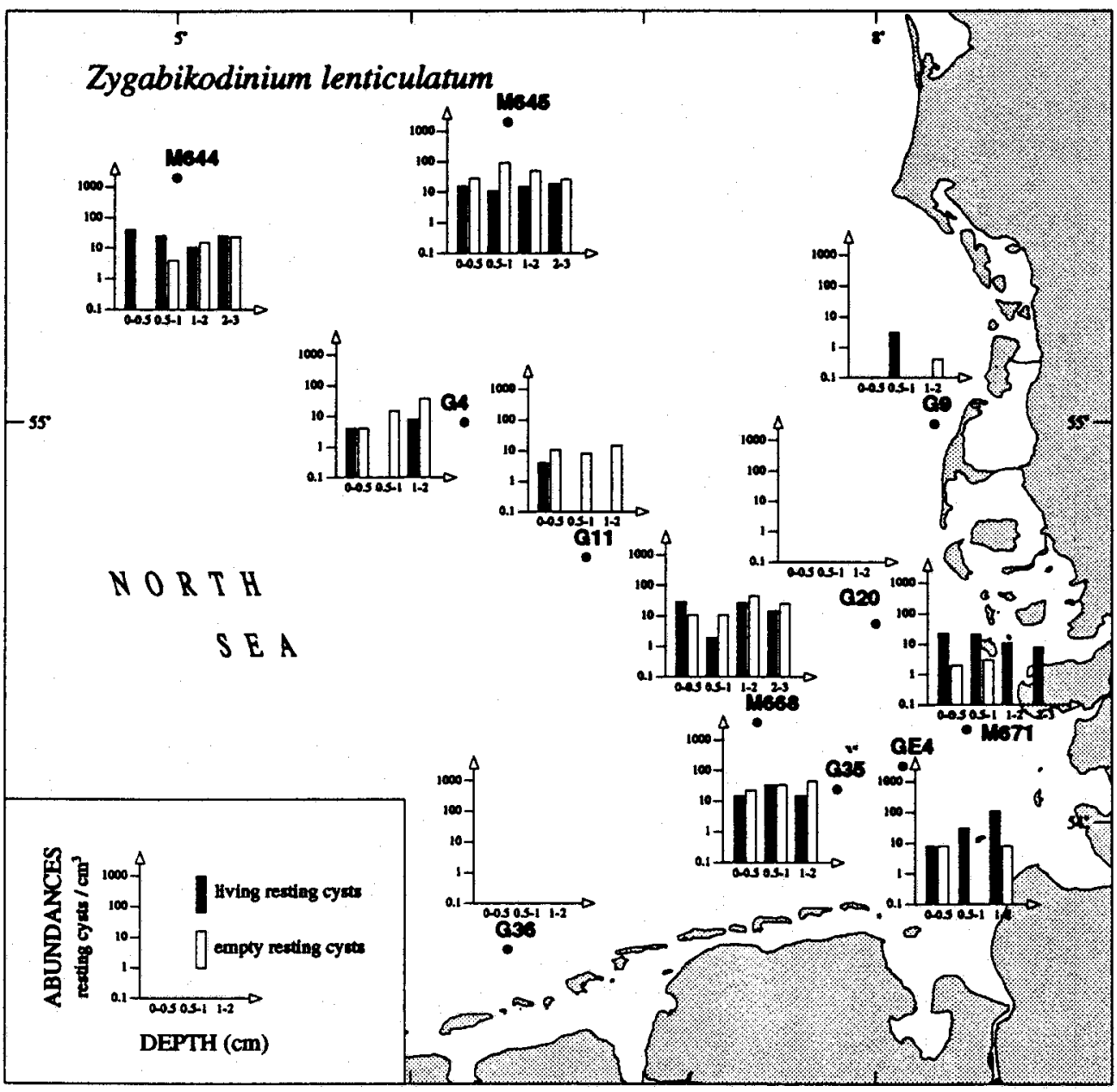

Fig. 5. Horizontal and vertical distribution of living and empty resting cysts of the dinoflagellate Zygabikodinium lenticulatum in the uppermost centimetres of sediment of the south-eastern North Sea (M: RV Meteor, October 1991; G: RV Gauss, March 1992)

analyzed sediment layers was $>1$. This tendency was prominent in Scrippsiella trochoidea and Peridinium dalei.

\section{DISCUSSION}

The term 'cyst' has been variously applied to different stages in dinoflagellate life histories (Dale, 1983), but two types are of particular biological interest: resting cysts and temporary cysts.

Resting cysts represent the thick-walled diploid stage of the sexual part of dinoflaqellate life cycles (Pfiester, 1989). In contrast to asexually formed temporary cysts, they 


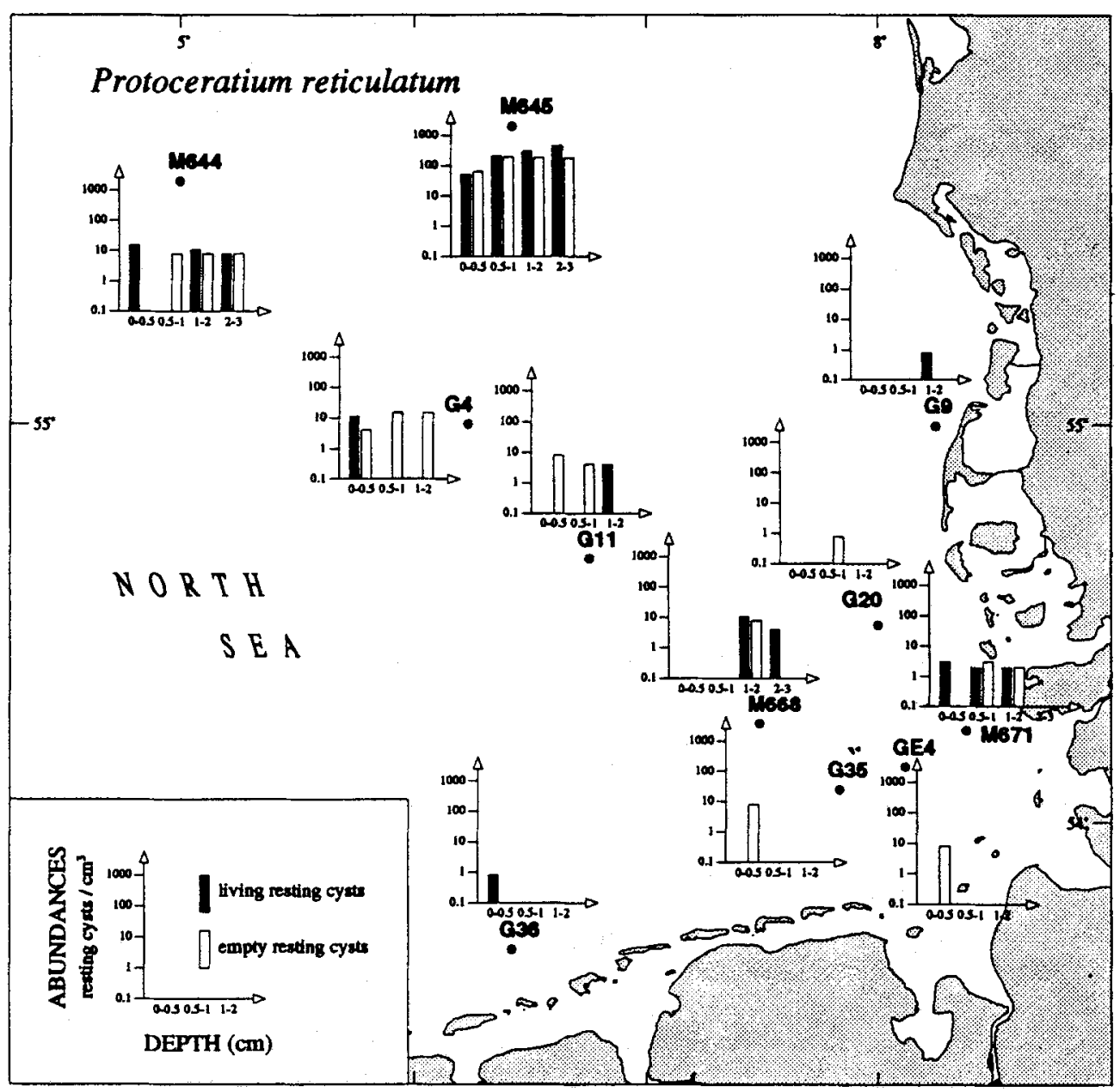

Fig. 6. Horizontal and vertical distribution of living and empty resting cysts of the dinoflagellate Protoceratium reticulatum in the uppermost centimetres of sediment of the south-eastern North Sea (M: RV Meteor, October 1991; G: RV Gauss, March 1992)

apparently cannot re-establish motile populations immediately because resting cysts may have an endogenously controlled mandatory resting period. This may last anywhere from weeks to months, during which germination is not possible, even when germination conditions are optimal (Anderson \& Keafer, 1987; Pfiester \& Anderson, 1987). These benthic stages can act as seed populations, inoculating the water column in the next season with vegetative cells to initiate blooms (e.g. Anderson \& Wall, 1978).

Laboratory experiments showed that resting cysts behave like fine silt particles in the sedimentary regime and are thus concentrated by sedimentary processes (Dale, 1976). Hence the abundance, distribution, and fate of deposited cysts are important variables. Potential areas of deposition are muddy or sandy muddy regions. In addition, the 
convergence zone at an estuarine front and its associated pycnocline enable the transfer of the encysting dinoflagellates from surface waters to their ultimate seedbed locations (Tyler et al., 1982). At higher sedimentation rates of terrigenous debris, cyst concentrations are likely to be lowered because of dilution or burial.

Stein (1883), credited with the first documentation of resting cyst formation, especially for Pyrophacus horologium, described the resting cyst of Gonyaulax spinifera as cyst of Cladopyxis brachiolata, both found near Helgoland. From freshwater samples, Stein described the resting cysts of Ceratium cornutum and $C$. hirundinella as $C$. macroceros. Hensen (1887) recorded from North Sea plankton samples the distinctive living resting cyst of Polykrikos schwartzii as an "umrindete Cyste", and possibly the resting cyst of Protoceratium reticulatum as Xanthidium multispinosum. The latter was also mentioned by Möbius (1887). In culture experiments with North Sea plankton, it was shown that most likely Fragilidinium subglobosum, as well as Cachonina niei, formed resting cysts (Stosch, 1969a, b). At present, however, no findings of cysts of these species have been reported in recent sediments. The only record of recent dinoflagellate cysts in bottom sediments of the south-eastern part of the North sea was given by Chowdhury (1982). He found only a few empty cysts of Gonyaulax spinifera, Protoperidinium of. leonis, $P$. conicoides and $P$. pentagonum. The dominance of Scrippsiella spp. cysts in this area of the North Sea - as demonstrated in the present study - could not be detected in Chowdhury's study because his harsh palynological preparation methods for plant spores only preserved some sporopollenin resting cysts of dinoflagellates and not the calcareous resting cysts of Scrippsiella spp. This also holds true for other investigations of North Sea sediments (Reid, 1974, 1975, 1977; Dale, 1976). Moreover, the dominance of Scrippsiella spp. cysts is remarkable, because as Dale (1986) pointed out, calcareous cysts are relatively more important in tropical and oceanic regions rather than in temperate ones. But Reid $(1975,1978)$ also noted that $S$. trochoidea cysts represent one of the common dinoflagellate cyst in the plankton from British waters.

Cyst morphology is increasingly regarded as an important parameter in the classification of modern dinoflagellates. Direct comparison of motile stage details with their cysts showed that cyst differences between species were more obvious (e.g. in Diplopsalid complex, Gonyaulax, Scrippsiella). Cyst studies are revealing a benthic view of dinoflagellate ecology and offer a potential tool for the prediction of future algal pests. They also may suggest the undetected presence of species in the water column (Nehring, 1994 a, in press), e.g. in the present study for Scrippsiella lachrymosa and possibly for $S$. trifida. Finally, cysts may be indicators of water circulation patterns (Nehring, 1993b), e.g. in the present study for Gonyaulax polyedra, Protoperidinium americanum and $P$. compressum. The findings of vegetative cells of these species are rarely reported from North Sea investigations and no reports are known for the German Bight (Elbrächter, pers. comm). Because of their small size, cysts are chiefly transported with the residual currents (Anderson et al, 1985b; Sarjeant et al., 1987) and perhaps here cysts are an indicator of water influx through the English Channel in recent years.

In studies about the vertical distribution of cysts, the bulk was found to occur in the uppermost two to three centimetre sediment layer (Anderson et al, 1982; Tyler et al., 1982; White \& Lewis, 1982; Nehring, 1994b, in press). Temperature (Anderson, 1980; Anderson et al., 1985a), light and oxygen (Anderson et al, 1987) are important factors that determine whether a newly-formed cyst will eventually germinate. When buried in 
deeper sediment layers by sedimentation or bioturbation (Anderson et al., 1982), cysts may contribute little to bloom initiation, due to anoxia and other inhibitory microenvironmental factors (Anderson et al., 1987).

Most cyst distribution studies have investigated the presence or absence of a sporopollenin cyst species. Quantitative cyst mapping is much more time-consuming. At present, only a few quantitative studies are available, mostly concerned with the abundance of the potentially toxic Alexandrium species (e.g. White \& Lewis, 1982; Anderson \& Keafer, 1985; Cembella et al., 1988).

The trend in the inshore to offshore diversity as well as the abundance of cysts in the investigated North Sea sediments can be correlated with the hydrographical and biological characteristics of surface water masses. Diatoms and the Haptophyceae Phaeocystis globosa predominate in the turbulent waters of the Wadden Sea, whereby dinoflagellates occur preferably in stratified waters further north (Reid et al., 1990; Hesse \& Nehring, 1993). Unfortunately very little information on the formation, occurrence and distribution of cysts in the plankton is available. Cysts were only found in a relatively small number of offshore samples, but when present, they often occurred in very large numbers (Reid, 1975,1978 ). In contrast, cysts in estuarine samples were observed throughout the year, but often in low numbers (<10 cysts/l) (Balch et al., 1983; Nehring, unpubl.).

The apparent discrepancy between the high cyst abundance in North Sea sediments and the poor record of motile stages in the water column is due to an accumulation of living cysts in the sediment over many years. This is reflected both by the fact that most cysts occur in subsurface sediment layers and by the observed low percentage of empty cysts. Little information is available about the germination rate of dinoflagellate cysts in natural waters. Anderson \& Keafer (1985) noted that the input of new cells from Alexandrium tamarense cysts is probably $<10 \%$ of the total cyst abundance. In contrast to sporopollenin cysts, the ratio of living to empty cysts of the calcareous cysts of Scrippsiella spp. may not only be influenced by a difference in germination rates, but also by the greater fragility of the empty cyst wall (Lewis, 1988). As a consequence of cyst accumulation, an unexpected number of cysts is present in the sediment for bloom initiation. Cysts are able to survive for years in anoxic sediments (Dale, 1983; Anderson et al., 1987), and bioturbation or resuspension events may bring buried resting stages back to the sediment surface or into the water column (Balch et al., 1983; Marcus \& SchmidtGegenbach, 1986).

In the present study, few toxic cysts of Alexandrium cf. excavatum and $A$. cf. tamarense were found. The absence of the detectable cysts of a species, however, does not necessarily indicate that a region is free from the threat of toxic blooms, since there are many toxic dinoflagellates without observed cyst-stages in their life cycle (e.g. Dinophysis spp.). Moreover, there is some evidence that factors such as cyst resuspension and current transport may repeatedly infect areas with toxic species (Cembella et al,, 1988; Anderson, 1989, Nehring, 1993b). In addition, exotic transport mechanisms of cysts, such as within the mud attached to birds legs, may be relevant in species dispersal (Langhans, 1925). As has been the case for many coastal marine macrofaunal organisms (for review, see Carlton, 1985), non-endemic dinoflagellate species can be inadvertently introduced to a region when their cysts are discharged with the ballast water in marine harbours (Hallegraeff \& Sumner, 1986; Hallegraeff \& Bolch, 1991). 


\section{CONCLUSION}

The role of the complex life-strategy of phytoplankton organisms for the development of algal pests in coastal zones has not been considered sufficiently in the past. The results, especially the relatively high abundance of cysts in recent sediments, demonstrate the potential importance of benthic resting cysts for the initiation of dinoflagellate blooms in the investigated area of the North Sea. Recognizing the important role of the resting cyst in the life cycle of dinoflagellates, there is an increasing need to study cysts in phytoplankton ecology in combination with studies of hydrodynamic, chemical and biological factors of the water column for a better understanding of the spatial and temporal dynamics of dinoflagellate blooms.

Acknowledgements. I thank Dr. K.-J. Hesse for valuable discussions. The comments of Dr. M. Elbrächter and three anonymous reviewers were greatly appreciated. W. Hukriede drafted the diagrams. Part of this study is supported by the Federal Environmental Agency, Environmental Research Plan of the Minister for the Environment, Nature Conservation and Nuclear Safety of the Federal Republic of Germany (Grant 10802 085/1), and the State of Schleswig-Holstein. This is publication No. 43 of the project "Ecosystem Research Wadden Sea".

\section{LITERATURE CITED}

Anderson, D. M., 1980. Effects of temperature conditioning on development and germination of Gonyaulax tamarensis (Dinophyceae) hypnozygotes. - J. Phycol. 16, 166-172.

Anderson, D. M:, 1989. Cysts as factors in Pyrodinium bahamense ecology. - ICLARM Conf. Proc. 21, 81-88.

Anderson, D. M. \& Keafer, B. A., 1985. Dinoflagellate cyst dynamics in coastal and estuarine waters. In: Toxic dinoflagellates. Ed. by D. M. Anderson, A. W. White \& D. G. Boaden. Elsevier, New York, 219-224.

Anderson, D. M. \& Keafer, B. A., 1987. An endogenous annual clock in the toxic marine dinoflagellate Gonyaulax tamarensis. - Nature, Lond. 325, 616-617.

Anderson, D. M. \& Morel, F. M. M., 1979. The seeding of two red tide blooms by the germination of benthic Gonyaulax tamarensis hypnocysts. - Estuar. coast. Shelf Sci. 8, 279-293.

Anderson, D. M. \& Wall, D., 1978. Potential importance of benthic cysts of Gonyaulax tamarensis and G. excavata in initiating toxic dinoflagellate blooms. - J. Phycol. 14, 224-234.

Anderson, D. M., Aubrey, D. G., Tyler, M. A. \& Coats, D. W., 1982. Vertical and horizontal distributions of dinoflagellate cysts in sediments. - Limnol. Oceanogr. 27, 757-765.

Anderson, D. M., Chisholm, S. W. \& Watras, C. J., 1983. Importance of life cycle events in the population dynamics of Gonyaulax tamarensis. - Mar. Biol. 76, 179-189.

Anderson, D. M., Coats, D. W. \& Tyler, M. A., 1985a. Encystment of the dinoflagellate Gyrodinium uncatenum, temperature and nutrient effects: - J. Phycol. 21, 200-206.

Anderson, D. M., Lively, J. J, Reardon, E. M. \& Price, C. A., 1985b. Sinking characteristics of dinoflagellate cysts, - Limnol. Oceanogr. 30, 1000-1009.

Anderson, D. M., Taylor, C. D. \& Armbrust, E. V, 1987. The effects of darkness and anaerobiosis on dinoflagellate cyst germination. - Limnol Oceanogr. 32, 340-351.

Balch, W. M., Reid, P. C. \& Surrey-Gent, S C, 1983. Spatial and temporal variability of dinoflagellate cyst abundance in a tidal estuary. - Can. J. Fish. aquat. Sci. 40 (Suppl. 1), 244-261.

Braarud, $T$., 1945. Morphological observations on marine dinoflagellate cultures (Porella perforata, Goniaulax tamarensis, Protoceratium reticulatum) - Avh norske Vidensk Akad. Oslo 1944 (11), $1-18$.

Braarud, T., 1957. Observations on Peridinium trochoideum (Stein) Lemm in culture. - Nytt Mag. Bot. 6,3942 .

Burkholder, J. M., Noga, E. J, Hobbs, C. H., Glasgow, H. B. \& Smith, S. A., 1992. New "phantom" dinoflagellate is the causative agent of major estuarine fish kills - Nature, Lond. 358, 407-410. 
Carlton, J. T., 1985. Transoceanic and interoceanic dispersal of coastal marine organisms, the biology of ballast water. - Oceanogr. mar. Biol. 23, 313-371.

Cembella, A. D., Turgeon, J., Therriault, J.-C. \& Beland, P., 1988. Spatial distribution of Protogonyaulax tamarensis resting cysts in nearshore sediments along the north coast of the Lower St. Lawrence estuary. - J. Shellfish Res. 7, 597-609.

Chowdhury, K. R., 1982. Distribution of recent and fossil palynomorphs in the south-eastern North Sea (German Bay). - Senckenberg. marit, 14, 79-145.

Dale, B., 1976. Cyst formation, sedimentation, and preservation, factors affecting dinoflagellate assemblages in recent sediments from Trondheimsfjord, Norway. - Rev. Palaeobot. Palynol. 22, $39-60$.

Dale, B., 1983. Dinoflagellate resting cysts, "benthic plankton". In: Survival strategies of the algae. Ed. by G. A. Fryxell. Cambridge Univ, Press, Cambridge, 69-136.

Dale, B., 1986. Life cycle strategies of oceanic dinoflagellates. - UNESCO tech. Pap. mar. Sci. 49, $65-72$.

Diwald, K., 1938. Die ungeschlechtliche und geschlechtliche Fortpflanzung von Gleodinium lubiniensiforme spec. nov. - Flora, Jena 131, 174-192.

Dodge, J. D., 1989. Some revisions to the family Gonyaulacaceae (Dinophyceae) based on a scanning electron microscope study. - Botanica mar. 32, 275-298.

Drebes, G. \& Elbrächter, M., 1976. A checklist of planktonic diatoms and dinoflagellates from Helgoland and List (Sylt), German Bight. - Botanica mar. 19, 75-83.

Evitt, W. R. \& Davidson, S. E., 1964. Dinoflagellate studies. I. Dinoflagellate cysts and thecae. Stanford Univ. Publs (Geol. Sci.) 10 (1), 1-12.

Guillard, R. R. \& Ryther, E. R., 1962. Studies on marine planktonic diatoms. I. Cyclotella nana Hustedt and Detonula confervacea (Cleve) Gran. - Can. J. Microbiol. 8, 229-239.

Hallegraeff, G. M. \& Bolch, C. J., 1991. Transport of toxic dinoflagellate cysts via ships' ballast water. - Mar. Pollut. Bull. 22, 27-30.

Hallegraeff, G. M. \& Sumner, C., 1986. Toxic plankton blooms affect shellfish farms. - Aust. Fish. 45, $15-18$

Hensen, V., 1887. Ueber die Bestimmung des Planktons oder des im Meere treibenden Materials an Pflanzen und Thieren - Jber. Kommn wiss. Unters. dt. Meere 5, 109-124.

Hesse, K.-J. \& Nehring, S., 1993. Phytoplanktonuntersuchungen. Meteor-Ber. 93-1, 70-74.

Huber; G. \& Nipkow, F., 1922. Experimentelle Untersuchungen über die Entwicklung von Ceratium hirundinella O. F. Müller. - Z. Bot, 14, 337-371.

Jonasson, A. \& Olansson, E., 1966. New devices for sediment sampling. - Mar. Geol, 4, 365-372.

Klebs, G., 1912. Über Flagellaten- und Algen-ähnliche Peridineen. - Verh. naturh.-med. Ver. Heidelb. 11, 369-451.

Langhans, V. H., 1925. Gemischte Populationen von Ceratium hirundinella (O.F.M.) Schrank und ihre Deutung. - Arch. Protistenk. 52, 585-602.

Lewis, J., 1988. Cysts and sediments: Gonyaulax polyedra (Lingulodinium machaerophorum) in Loch Creran. - J. mar. biol. Ass. U.K. 68, 701-714.

Lewis, J., 1991. Cyst-theca relationships in Scrippsiella (Dinophyceae) and related orthoperidinioid genera. - Botanica mar. 34, 91-106.

Lohmann, H., 1910. Eier und Cysten des nordischen Planktons. In: Nordisches Plankton. (Zool. T.) Ed. by K. Brandt \& C. Apstein. Lipsius \& Tischer, Kiel 2, 1-20.

Marasovic, I., 1989. Encystment and excystment of Gonyaulax polydera during a red tide. - Estuar. coast. Shelf Sci, 28, 35-41.

Marcus, N. H. \& Schmidt-Gegenbach, J., 1986. Recruitment of individuals into the plankton: the importance of bioturbation. - Limnol. Oceanogr. 31, 206-210.

Matsuoka, K., 1985. Archeopyle structure in modern gymnodinialean dinoflagellate cysts. - Rev. Palaeobot: Palynol. 44, 217-231.

Matsuoka, K., Fukuyo, Y: \& Anderson, D. M., 1989. Methods for modern dinoflagellate cyst studies. In: Red tides. Ed. by T. Okaichi, D. M. Anderson \& T. Nemoto. Elsevier, New York, 461-479,

Möbius, K., 1887. Systematische Darstellung der Thiere des Planktons, gewonnen in der westlichen Ostsee und auf einer Fahrt von Kiel in den atlantischen Ozean. - Jber. Kommn wiss. Unters. dt. Meere $5,109-124$ 
Nehring, S., 1992. Cystenbildung als Lebensstrategie bei Dinoflagellaten. - Jber. Forsch. Technol. Zent. Westküste Büsum 1991, 12-14.

Nehring, S., 1993a. Mechanisms for recurrent nuisance algal blooms in coastal zones: resting cyst formation as life-strategy of dinoflagellates. In: Interdisciplinary discussion of coastal research and coastal management issues and problems. Ed. by H. Sterr, J. Hofstede \& H.-P. Plag. Lang, Frankfurt, 454-467.

Nehring, S., 1993b. Gymnodinium catenatum in German coastal waters. - Harmful Algae News, 7, 1 and 4.

Nehring, S., 1994a. First record of living Alexandrium minutum resting cysts in the Western Baltic. Harmful Algae News, 9, 1-2.

Nehring, S., 1994b. Spatial distribution of dinoflagellate resting cysts in recent sediments of Kiel bight, Germany (Baltic Sea): - Ophelia 39, 137-158.

Nordli, E., 1951. Resting spores in Goniaulax polyedra Stein.-Nytt Mag. Naturvid. 88, $207-212$

Pfiester, L. A., 1989. Dinoflagellate sexuality. - Int. Rev. Cytol. 114, 249-272.

Pfiester, L. A. \& Anderson, D. M., 1987. Dinoflagellate reproduction. In: The biology of dinoflagellates. Ed. by F. J. R. Taylor. Blackwell, Oxford, 611-648.

Reid, P. C., 1974. Gonyaulacacean dinoflagellate cysts from the British Isles. - Nova Hedwigia 25, $579-637$.

Reid, P. C., 1975. A regional sub-division of dinoflagellate cysts around the British Isles. - New Phytol. 75, 589-603.

Reid, P. C., 1977. Peridiniacean and Glenodiniacean dinoflagellate cysts from the British Isles. Nova Hedwigia 29, 429-463.

Reid, P. C., 1978. Dinoflagellate cysts in the plankton. - New Phytol. 80, 219-229.

Reid, P. C., Lancelot, C., Gieskes, W. W. C., Hagmeier, E., \& Weichert, G., 1990. Phytoplankton of the North Sea and its dynamics: a review. - Neth. J. Sea Res. 26, 295-331.

Sarjeant, W. A. S., Lacalli, T. \& Gaines, G., 1987. The cysts and skeletal elements of dinoflagellates, speculations on the ecological causes for their morphology and development. - Micropaleontology $33,1-36$.

Steidinger, K. A., 1975. Basic factors influencing red tides. In: Proceedings of the first international conference on toxic dinoflagellate blooms. Ed. by V. R. LoCicero. Mass. Sci. Technol. Found. Wakefield, 153-162.

Stein, F., 1883. Der Organismus der Infusionstiere. 3,2: Der Organismus der arthrodelen Flagellaten. Engelmann, Leipzig, 30pp.

Stosch, H. A. von, 1969a. Dinoflagellaten aus der Nordsee I. Über Cachonina niei Loeblich (1968), Gonyaulax grindleyi Reinecke (1967) und eine Methode zur Darstellung von Peridineenpanzern. - Helgoländer wiss. Meeresunters. 19, 558-568.

Stosch, H: A. von, 1969b. Dinoflagellaten aus der Nordsee II. Helgolandinium subglobosum gen. et spec. nov. - Helgoländer wiss. Meeresunters. 19, 569-577.

Taylor, F. J. R. \& Gaines, G,, 1989. Dinoflagellate cyst morphology: an analysis based on laboratory observations of encystment. In: Red tides. Ed. by T. Okaichi, D. M. Anderson \& T. Nemoto. Elsevier, New York, 295-296.

Tyler, M. A., Coats, D. W. \& Anderson, D. M., 1982. Encystment in a dynamic environment, deposition of dinoflagellate cysts by a frontal convergence. - Mar. Ecol. Prog. Ser. 7, 163-178.

Wall, D., 1965. Modern hystrichospheres and dinoflagellate cysts from the Woods Hole region. Grana palynol. 6, 297-314.

Wall, D. \& Dale, B., 1966. "Living fossils". in western Atlantic plankton. - Nature, Lond. 211, 1025-1026.

Wall, D. \& Dale, B., 1968a. Modern dinoflagellate cysts and evolution of the Peridiniales. Micropaleontology 14, 265-304.

Wall, D. \& Dale, B., 1968b. Quaternary calcareous dinoflagellates (calciodinellidae) and their natura] affinities. - J. Paleont. 42, 1395-1408

White, A, W. \& Lewis, M., 1982. Resting cysts of the toxic red tide dinoflagellate Gonyaulax excavata in Bay of Fundy sediments-Can. J. Fish. aquat. Sci. 39, 1185-1194.

Zederbauer, E, 1904. Geschlechtliche und ungeschlechtliche Fortpflanzung von Ceratium hirundinella. - Ber. dt. bot. Ges. 22, 1-8. 